\title{
The Constitution of Somaliland: The Problem of Constitutional Generations and Clan Dissolution
}

\author{
Mario I. Aguilar \\ University of St. Andrews, St Andrews, Scotland \\ Email: mia2@st-and.ac.uk
}

Received 4 May 2015; accepted 10 October 2015; published 13 October 2015

Copyright (C) 2015 by author and Scientific Research Publishing Inc.

This work is licensed under the Creative Commons Attribution International License (CC BY). http://creativecommons.org/licenses/by/4.0/

cc) (7)

\section{Open Access}

\section{Abstract}

This paper outlines the history, formation and general principles of the 2001 Somaliland Constitution. The people of Somaliland declared independence from Somalia in 1991 returning to the boundaries that had marked the British Protectorate of Somaliland until 1960, holding successful democratic elections, and establishing peace and stability, becoming an exception state within a war-torn region. In a contribution to the sociology of law and the wider knowledge of Somaliland this paper outlines the unifying principles within the Constitution, principles that are taken from the unity of religion (Islam), and the desire to exercise unity in diversity through traditional institutions of conflict resolution with the inclusion of universal principles of human rights law.

\section{Keywords}

Somaliland, African Constitutions, Sociology of Law, Sociology of Religion, Karl Mannheim, Constitutional Generations, Islam in the Horn of Africa, State Formation

\section{Introduction}

On 18 May 1991, participants at the Grand Conference of the Northern Peoples (Conference of the Somaliland Communities in the 2010 Constitution, 27 April-5 May 1991) meeting at Burao announced the withdrawal of the peoples from north-west Somalia from the union that had been agreed between British Somaliland and Italian Somalia in 1960 and that had given birth to the nation of Somalia ${ }^{1}$. The territory that was leaving Somalia kept the same borders of the former British Protectorate of Somaliland with Djibouti (French Somaliland) to the

\footnotetext{
${ }^{1}$ For a comprehensive history and interpretation of these processes of self-determination and break with Somalia see (Bradbury, 2008:
} Chapter 2, 22-49). 
north, Ethiopia to the south-west and Somalia to the east and the interpretation of these events in the constitution suggested an act of "independence" (Dastuurka Jamhuuriyadda Somaliland, 2000, "Preamble"). Those meeting at Burao were the leaders of the Somali National Movement (SNM) and elders of the Somali northern clans ${ }^{2}$.

While Somaliland has failed to receive international recognition as a new state by other nations because of the preference by European countries for a united Somalia it has acquired nevertheless a relatively enduring peace and political stability (Somaliland Ministry of Foreign Affairs, 2002). The Burao Declaration has allowed since 1991 the establishment of an elected government, an agreement on a national development plan, and the existence of a national Constitution as a body of 130 articles that define the state of Somaliland, its political powers, its legislative institutions and the structure of government of a working modern state. For those who support Somaliland's international recognition as a state the constitutional text has become a marker of possible acceptance because once there is a constitutional text commonly held and equal rights and obligations for all citizens there are the trimmings of a state ${ }^{3}$. However, while Somaliland is perceived as a success vis-à-vis Somalia the international community is not yet willing to intervene and support actions from the African Union that could provide the recognition of Somaliland by other African member states. The reasons for this failed recognition are varied, but the central reason relates to the recent failure of South Sudan to manage violence and conflict despite its independence and the significant recognition and financial aid provided by the United Nations, the African Union and the European Union.

One of the aspects less researched in the success of Somaliland has been the text of the Constitution which in itself provides a way forward between a Muslim centred principles of societal organisational law and the recognition of universal human rights to the individual, to women and to traditional institutions and their leaders. The Constitution has been and it will provide stability and peaceful governance to Somaliland because even in the greatest possible clan disagreements there are in place fundamental principles of legal order that connect the societal, the religious and the political.

This paper provides a general analysis of the history and formation of the Somaliland Constitution and its understanding of religion, politics and the rights of the individual within the state. Within the Somaliland Constitution a Somaliland constitutional body has suggested that nationhood rather than clanship is the essence of the nation. By stating the primacy of the nation over clan relations it has provided the foundations for a societal constitution based on religion rather than ethnicity creating a fresh approach to the problem of what I have labelled following the sociologist Karl Mannheim "the problem of constitutional generations". Thus, this paper provides a contribution not only to the scholarship and public understanding of Somaliland but also to the sociology of law. In the conclusions to this paper I argue that different generations of ethnic Somali have had different experiences of constitutional experiments based on clanship creating what I would label "the problem of constitutional generations" and that these tensions could be considered creative in the ongoing formation of a unified Somaliland society. The Somaliland Constitution has provided a challenge to those who have perceived a "greater Somalia" as a stateless nation by establishing a set of common norms that could work in order to enforce agreed societal understandings. This ongoing process could bring a long term peace through the skeletal principles of a state that focuses on the development of a unified sense of purpose expressed through development expressed concretely in the re-building of educational and health structures within a very unstable and war-torn larger Horn of Africa.

\section{Traditional Order and Historical Developments}

In his seminal work on the northern Somali, I.M. Lewis argued that "generally only at the level of the clan is there some degree of association between people and a particular stretch of territory" (Lewis, 1982: 47). Clans

\footnotetext{
${ }^{2}$ The seminal work on pastoralists of northern Somalia remains Lewis (1982). Frequently attacked by those who accused him of describing social institutions without social change, I.M. Lewis stated that "I was also strongly attracted by the heavy currents of Somali nationalism and hence sought to explore how modern Somali political movements related to the traditional social order" (Lewis, 1982, "Preface to the 1982 Edition”, xi-xvii at xi). For the historical developments of the Somali National Movement (SNM) see Lewis (1994d).

${ }^{3}$ Somaliland has received recognition by two local councils in the UK, i.e. Sheffield and Cardiff. On 2 April 2014 Sheffield local council approved the following motion: "the British Government to recognize Somaliland as an independent state and to encourage other governments around the world to do the same", see "Somaliland: Senior Legislature and Administration Operatives in Sheffield for Council Vote on Recognition", Somaliland Sun 2 April 2014 at

http://somalilandsun.com/index.php/politics/5430-somaliland-senior-legislature-and-administration-operatives-in-sheffield-for-council-voteon-recognition On 28 March 2015 Cardiff City Council also recognized the right by Somaliland to self-determination, see "Somaliland: British Landers Welcome Cardiff Recognition Vote”, Somaliland Sun 28 March 2015 at

http://somalilandsun.com/index.php/component/content/article/7144-somaliland-british-landers-welcome-cardiff-recognition-vote
} 
moved through territories with their herds according to the seasons (dry and wet) whereby "no clan or lineage has a specific title to grazing backed by ritual or mystical sanctions” (Lewis, 1982: 49). The study that I.M. Lewis conducted between 1955 and 1957 in northern Somalia and its related publications have remained the classic work that helped understood the Somali clan institutions and segmentary lineages that later evolved within the localized politics of Somalia ${ }^{4}$. After the military coup of 1969, the creation of the Somali Democratic Republic and the civil war that took place from 1991 onwards, clan affiliation was used as a classificatory devise for violence, division, and pillage.

Historically, the Somali clans evolved around a proto-Somali social organization and religion that shared the same monotheistic concept of God as sky (Waaq), a concept shared by the Oromo (especially Boorana and Guji, i.e. Waqqa), the Konso, Burji, Haddiyya, Tasmai, Dasenech, Arbore, Elmolo, Basyo, Rendille, Dahalo and Somali; all Cushitic pastoralists living in pre-colonial times in the lands that later were to become the states of Kenya and Ethiopia (Mansur, 1995: 119-120). It was later, and with the Islamic conversion and unification of the Somali under the symbolic banner of Islam that a systematic configuration, a mythical chart of clans and lineages that I.M. Lewis in 1957 named the "total Somali genealogy" was produced, a 140 page document distributed to the colonial administration in Somaliland (Lewis, 1957). This Arabic document made possible for any Somali to relate to the past and according to Cassanelli it "highlighted the dynamic aspects of the segmentary lineage system” (Cassanelli, 2010: 53).

The arrival of Islam in Somalia could be dated back to the Caliphate of Abdulmalik Ibn Marwan (685-705) when parts of Somalia fell into the hands of Umayyad conquerors (Mohamed Haji Mukhtar, 1995: 3). The Muslim army led by Syrian General Musa Ibn Umar al-Khath'ami conquered Mogadishu and Kilwa and as customary insured that taxes were collected, that the Qura'n was taught, that security was a reality and that the population remained loyal to the Islamic state in Damascus. Thus, while Islam armies, envoys and rulers, as well as Arab traders, managed over the centuries to establish Islam within southern Somalia (known to the Arabs as Bilad al-Zinj meaning "the land of the blacks") there was a clear unification towards a Muslim Somalia when the "total Somali genealogy" became an instrument of that represented a whole nation, called by Abbink as "a major cultural achievement of the Somali people” (Abbink, 2009).

The "total Somali genealogy" outlined as a social system of classification by I.M. Lewis was not recorded, according to Cassanelli, by foreign travellers in the $19^{\text {th }}$ century (Cassanelli, 2010: 56). However, with the advent of the British colonial administration its existence became apparent as foreign civil servants asked questions about socio-religious and political organization in order to provide consistent indirect rule. Foreigners were told single or total genealogies by local Somali genealogists and interpreters versed in Arabic and who were in possession of Arabic manuscripts with their own family genealogies (Cassanelli, 2010: 57; cf. 2006). In some cases, prominent families produced such genealogies in order to increase their religious pedigree and to make colonial administrators aware of their political importance (Reese, 2008: 65-80; Lewis, 2001). Within the religious revival of the mid-twentieth century the textualization of a single Somali genealogy proved vital in order to mediate the tension between a universal community of Muslim believers (the umma) and the lineage and clan affiliation which created social divisions rather than religious unity ${ }^{5}$. Such tension had been challenged during the $19^{\text {th }}$ century when the spread of Sufi religious orders managed to attract members from different clans who showed a stronger adherence to their religious community rather than to their clan affiliation. The Sufi members of the jamea [Sufi religious settlement] searched for their genealogies in relation to Islam and the Prophet rather than in relation to their clans, a fact that created a need for all Somali to search for a clan genealogy closely linked to a Muslim genealogy (Helander, 1999: 46). The ethnographic and historical difficulties of the "total Somali genealogy” are plentiful and were outlined by I.M. Lewis in his critique of an administrative colonial understanding of the Somali.

The exit of Siyaad Barre's precipitated a kind of violence that no scholar was able to predict. The fight for control by different clans and the suffering inflicted on the population provided a challenge to clans understood as Tol meaning "that which binds", literally "that which sews together” (Ahmed, 1995: xi). Two scholarly views

${ }^{4}$ I.M. Lewis had already done some linguistic and bibliographical research on the southern Somali as well as the northern Somali (Lewis, 1955). In the second edition published in 1994 Lewis added an appendix with a study of the inter-river area that he carried out in 1957,1962 and 1964 (Lewis, 1994a, cf. Lewis, 1994c).

${ }^{5}$ An earlier religious revival had taken place in the later $16^{\text {th }}$ and $17^{\text {th }}$ centuries when Sada-Ashraf families from the Hadhramaut settled in the Horn of Africa. They claimed noble birth and powerful Baraka while being involved in wars against Christian Ethiopia. Their arrival due to drought and famine could have triggered an earlier systematization of clan genealogies in connection with Islam by local intellectuals (Hersi, 1977: 235-241). 
were put forward: in the first one clans were understood as groups that bind together whereby any violent excesses have nothing to do with the sense of clans and in the second one a challenge is made to the sense of clan as a static reality, thus avoiding the fact that clan relations are affected by socio-political realities and new realities. The "invention of Somalia" as an intellectual work of realism and pragmatism argued, for example, that Somali history was never studied properly and that those portraying the "total Somali genealogy" together with the colonial administrative history of order and nomadism did not allow issues of conflict to be understood as part of the historical dynamics of Somalia.

There is a paradox in the understanding of Somalia as a nation of clans in that Somali share a common language, social institutions and religion; however, the clans "traditionally lack the concept of state as a hierarchical power” (Mansur, 1995: 107). With independence the elites that ruled the country failed to advance the country's infrastructure and the national budget was used to keep bureaucratic machinery based on the colonial experience. With more than $60 \%$ of Somali considering themselves as nomadic and the ideal of a Somali the pastoral elites that became involved in the government brought with them the sense of a noble cast. They followed their pastoral roots by considering as humiliating all manual jobs such as blacksmithing, shoemaking, leather tanning, farming and fishing (Mansur, 1995: 113-114). The interests of clans and sub-clans prevailed and in the last elections of the First Republic more than 80 political parties provided candidates for the elections. Barre's military coup and later years in office aimed at the economic development of Somalia; however, the clan system that allowed for fragmented interests destroyed any possibilities of a common law of cooperation as the nation state had already destroyed customary law that governed the relations between one clan and another in order to cooperate together within grazing and water rights. The presence and absence of the two systems: the end of the clan system in order to create a state and the collapse of the state created a vacuum in which clans exercised the same rights they had previously-they could steal camels from each other as a matter of honour and not as a matter of shame (Mansur, 1995: 110-111).

The history of the clans and the mythical trope of majority and minority clans is based then on a genealogical contradiction but a real life definition that affects the lives of all Somali today. In genealogies precedence of importance is given by the order of birth; however, in Somali lineages the importance of a lineage is directly related to the number of members on the ground so that "the genealogies of numerically large lineages [...] are longer than those of smaller and weaker groups” (Lewis, 1994b: 100).

\section{Constitutional Principles}

The First Constitution of Somaliland came into effect on 26 June 1960 when the British Protectorate of Somaliland became independent Somaliland. Thus, the First Constitution stated that "The territory of Somaliland shall be all that territory which on the commencement of this Constitution, is comprised in Her Britannic Majesty's Protectorate of Somaliland” (First Constitution of Somaliland 26 June 1960, part I, § 2.1). Independent Somaliland lasted for five days when following ideas of a Greater Somalia Somaliland joined the Italian administered UN Trust Territory of Somalia on 1 July 1960. Thirty years passed until Somaliland proclaimed its independence coinciding with the collapse of the Siyad Barre regime in January 1991.

The 1991 Burao Declaration proclaimed that the clans that inhabited north-western Somali, from then onwards known as Somaliland, would cease their strife in order to create the foundations for an independent nation. Thus, two foundational principles were established: the unity in the historical belonging to a region previously known as British Somaliland and the commonality of religion and history that could prevail over the divisions based on ethnicity. Clans didn't cease to exist but the social relations between members of those clans in order to access resources and conduct their sociability was not based on clan hegemony and historical access, for example to water or grazing, but on equality in law ${ }^{6}$.

It must be noted that in May 1993 and after two years in power the Somali National Movement (SNM) handed over power to the elected president in Borama (MI Egal). This was in line with the SNM constitution which stated that once the country is liberated, SNM will rule the country for 2 years and transfer power to a civilian elected government ${ }^{7}$. Within a meeting of local representatives comprising all clans that resided in Borama over a period of four months. The traditional ways of reaching agreement on the future of Somaliland were

\footnotetext{
${ }^{6}$ Marleen Renders, examining the whole process of nation-building from 1991 to 2007 has argued that in the case of Somaliland "modern" and "traditional" institutions and personnel co-exist, overlap and become reinvented in the context of political competition in the newly founded “state” (Renders, 2007).
}

${ }^{7}$ Ali A. Awale to Mario I. Aguilar 2 June 2015. 
followed, even when voting was allowed. Consensus was reached before the voting and if consensus was not ready chairs delayed the voting. However, one of the central factors that activated a positive trust towards consensus was the issue of fear as participants feared that a lack of consensus would lead Somaliland into the chaos, suffering and war present in Somalia. Thus, Michael Walls has argued that "the effect of southern disorder in focusing northern minds has been so pronounced as to demand a mention” (Walls, 2009: 389; cf. 2011).

The first main Constitutional document of the independent Somaliland was the National Charter (Axdi Qarameed), which was signed by the Conference of the Somaliland Communities in 1993 in Borama. The Charter was approved by the constituent assembly of the 150 nominated representatives of all the Somaliland Communities on 25 April 1993 and was signed, and came into effect, on 3 May 1993. Under Article 5, the Charter was to be in force for a period of two years and was to be replaced by a Constitution which was to be approved in a public referendum. This was not possible by 1995 and the House of Elders extended the period of the operation of the Charter (and the term of the President elected at 1993 Conference) for 18 months from September 1995. This was followed by the preparation of the first Somaliland constitution, which was adopted at the conference of the Somaliland Communities in Hargeisa in February $1997^{8}$. Under article 151, the constitution was to be implemented for a period of three years from its approval in February 1997 and was to come into force fully once a referendum had been held. There was a provision for this interim period to be increased by the two Houses of Parliament, and in early 2000, the two Houses voted that the period be increased by one year. This was primarily to give more time for the completion of the revision of the constitution (before its submission to the nation at a Referendum) and for putting in place the laws and mechanisms for changing the "representative" democracy in Somaliland to a popular democracy based on the direct elections of the President and the Parliament of Somaliland.

Although initially the Somaliland government proposed fairly extensive amendments to the constitution in 1999, the final revised constitution was not very different from the previous one and the reduction of the number of articles from 156 to 130 was largely achieved by the amalgamation of some articles, rather than by extensive repeals. Unlike the earlier draft proposals, the parts of the constitution relating to directive principles and to human rights were retained. Thus, the revisions tidied up the constitution while no fundamental changes were made.

\section{The 130 Articles: Religion and Politics}

The Constitution of Somaliland (“Constitution”) was adopted by the Houses of the Parliament of Somaliland on 30 April 2000 and publicly approved in a referendum held on 31 May 2001 by 97\% of voters. Its re-published version consists of a Preamble (Arar) and five main chapters (Qaybo) each of which is sub-divided into Parts (Xubno) with a total of 130 Articles (Qodobo), twenty six less than those contained in the 1997 provisional text which contained 156 Articles (Dastuurka Jamhuuriyadda Somaliland, 2000).

The "Constitution" is not a secular document in that it is proclaimed "in the name of Allah, the Compassionate and the Merciful”. It presumes and assumes a unity in Islam and a community of Islam (umma) that extends to all Somali within Somaliland ${ }^{9}$. The desire within the constitution is to have a state based on "equality and justice" that can be built by the Somaliland nation defined as "a family that has everything in common, such as religion, culture, customs and language” (“Constitution”, Preamble). Within this national project all citizens have “equal status” (“Constitution”, Preamble).

The "Constitution" identifies the newly independent country as "The Republic of Somaliland” and identifies this country with that territory which gained independence by the United Kingdom on 26 June 1960 and which joined Somalia in order to become the Somali Republic on 26 June 1960 (“Constitution”, article 1.1). Its borders are the Gulf of Aden to the north, Somalia to the east, the Federal Republic of Ethiopia to the south and the west, and the Republic of Djibouti to the north-west ("Constitution”, article 2.2). The capital of Somaliland is named

\footnotetext{
${ }^{8}$ Members of the Constitution Preparation Committee at the 1997 Hargeisa Conference: Sh. Cabdilaahi Sh. Call Jawhar (Chairman), Maxamed Axmed Cabdulle (Deputy Chairman), Clqaadir X. Ismaaciil Jirde (Secretary), Sh. Maxamuud Suufi Muxumed, Maxamed Siclid Maxamed (Gees), Sh. Call Sh. Cabdi Guuled, Faysal Xaajl Jaamac (Counsel), Cismaan Xuseen Khayre (Judge), Prof. Faarax Cabdlaahi Farlid, Prof, Maxamuud Nuur Caalin, Xasan Cabdi Xabad, Axmed Macaim Jaamac, Yuusuf Aadan Xuseen, Cismaan Cali Blue, and Maxamed Jaamac Faarax.

${ }^{9} \mathrm{~A}$ thorough study of religion within the state constitutions of nations of the Horn and East Africa suggests that national constitutions are no secular documents but that central discussions on those constitutional documents and their revisions pertain to issues of national constitutionalism and religious laws within nations. Thus, the 2010 Kenya Constitution allowed for Khadi Courts based on sharia law for Muslims within a majority Christian country rather than suggesting a principle of secularism based on universal human rights (Aguilar, 2015).
} 
as Hargeisa and the citizens of Somaliland are those who are descendants of the residents of Somaliland on or before 26 June 1960 (“Constitution”, articles 3 \& 4).

The religion of Somaliland is Islam with the proviso that the promotion of any other religion in Somaliland is prohibited ("Constitution", article 5.1). The laws of the contrary are grounded in sharia law fulfilling sharia principles and discouraging "immoral acts and reprehensible behaviour" within an Islamic calendar based on the hijra, and the Gregorian calendar (“Constitution”, article 5.2-5.4). Regarding a national language the "Constitution” establishes Somali as the official language, Arabic as the second national language and other languages are permitted according to need (“Constitution”, article 6.1-2). The national flag established by the constitution has three parallel sections and on the top section of green colour it has the following phrase in white colour and in the Arabic language: La llaaholla-Allaah Muhammad Rasuulah-Allaah (there is no God, but Allah and Mohammad was his Prophet, “Constitution”, article 7.1). The national emblem reinforces the Somaliland adherence to Islam adopting a coffee coloured falcon with the words, inscribed on its breast, "Allahu Akbar" (God is great, “Constitution”, article 7.2). The religious understanding of life and creation imbedded in the constitution continues in the section on human rights when it declares that "human life is the gift of Allah and is beyond price" (“Constitution", article 24.1). Thus, while upholding the right to life of every citizen, the constitution also provides for the death penalty if a court of law within Somaliland so decides (“Constitution”, article 24.1).

The "Constitution” provides a double-lawful coexistence between principles of sharia and adherence to Islam with tenets of human rights law to be found in most contemporary constitutions and required by the international community in order to accept a constitutional instrument of national legislation. Thus, the "Constitution” prohibits "physical punishment and any other injury to the person" and upholds the right of every person "to have his dignity, reputation and private life respected" (“Constitution”, article 24. 2-3). Further, and within the protection of human rights the "Constitution" states no time limitation period for crimes against human rights such as atrocities, extra-judicial killings, torture and other similar acts (“Constitution”, article 24.4). At the centre of this constitutional move forward is the principle of law not always upheld in emerging African constitutions that "an accused person is innocent until proven guilty in a court” and has the right to legal counsel and legal defense, provided free by the state, as well as the right to appeal a sentence (“Constitution", articles 26.3, 27.1, 27.6 \& 28.2-3).

Discussions on religion and public politics re-surface within the constitution at article 33 that needs to be read in connection with article 5.1 that had previously stated that "the religion of Somaliland is Islam with the proviso that the promotion of any other religion in Somaliland is prohibited". For article 33 declares the right of freedom of belief for every citizen without being compelled to adopt another belief and in doing so makes a difference between religion and belief: "Every person shall have the freedom of belief, and shall not be compelled to adopt another belief" (“Constitution”, article 33.1). If one were to read both articles together it is clear that in article 5.1 the religion spoken of is Islam, the only religion allowed in Somaliland. Thus, the legality of "belief" expresses a diversity of Muslim traditions within the unity of Islam so that belief and religion within Somaliland are to be by law non-sectarian among Somaliland Muslims. Conversion and the practice of any other religion outside Islam becomes unlawful because the constitution has a firm foundation in sharia law and the constitution further states that "Islamic Sharia does not accept that a Muslim person can renounce his beliefs" ("Constitution”, article 33.1).

Within such freedom of religious faith and practice the mosque is "a blessed place and deserves veneration" (“Constitution", article 33.2). It is at the mosque where faith is lived and proclaimed and where religion and politics meet as "it is the place for preaching religion and for providing the nation guidance in spiritual and temporal matters" ("Constitution", article 33.2). The duty of the state as proclaimed in the "Constitution" is to provide "general protection and any practicable support” (“Constitution”, article 33.2). Further, the "Constitution” prohibits any preaching that could divide the nation labelling such preaching as "sedition” ("Constitution”, article 33.2).

The constitutional oath, administered by the Chairman of the Supreme Court who is Chairman of the Constitutional Court as well, reflects the central chore of Islam within the "Constitution" and its formula reads as follows: "I swear by Allah that I shall be true to the Islamic religion and my Somaliland country, and shall manage my people in equity and justice so long as I hold office" ("Constitution", article 129). Religion becomes part of the duties of a citizen rather than an individual choice and every citizen has the duty to defend Somaliland and its religion [Islam] (“Constitution”, article 34.1). The same spirit is shown within the articles dealing with the possibility of future amendments to the "Constitution" so that no proposals to amend or change the "Constitu- 
tion" can be made if they are in conflict with the principles of Islamic Sharia because the "Constitution” is based on Islamic principles (“Constitution”, articles 127.a \& 128.1).

The state of Somaliland is within the "Constitution" not only the result of the historical British presence in the old colonial protectorate or the wish and agreement of the northern peoples but it is a state that has been created by divine will and right. This constitutes a very strong statement in an era of secular and religious-conciliatory constitutional agreements for peace that look at the present and the future erasing the past. The "Constitution" returns to the past quite strongly and provides a common point of communal agreement among Somalilanders advocating divine creation and law. Thus, the text states that "Allah who created the Somaliland nation in this land has endowed it with sovereign status and powers" ("Constitution", article 37.1). That sovereignty is not bestowed on a monarch or a leader but on the people of Somaliland who in turn "have vested their sovereign powers, as set out in this Constitution, in a state founded on, and which shall act in accordance with, the Constitution" (“Constitution”, article 37.1).

The laws that operate within Somaliland are passed through Parliament consisting of two houses: the House of Representatives and the House of the Elders ("Constitution", article 38.1). Within the duties of Parliament such as the protection and security of its citizens the "Constitution" mentions the "adoption of the Republic of Somaliland of all the laws necessary in a Muslim state" ("Constitution", article 38.4.b). The requirements for election to the House of Representatives reinforces the fact that Somaliland is a Muslim state by requiring that any candidate for election be a Muslim and "must behave in accordance with the Muslim religion" ("Constitution", article 41.1). However, following traditional values of age and seniority within Somaliland society this candidate cannot be younger than thirty-five years of age ("Constitution", article 41.2). This parameter of age is of importance when there are moments in which offices have not been filled or elected, for example, during the convening of members of a newly-elected House of Representatives. So that after the Chairman of the Supreme Court administers the oath of office to the members the first meeting of the House is chaired by the oldest member (in age) while members of the House elect a Speaker and a Deputy Speaker ("Constitution", article 44.3).

One important innovation within the "Constitution" is the formation of the second part of the legislative that is the House of Elders with the remit of reviewing the legislation passed by the House of Representatives before it is forwarded to the President ("Constitution", article 57: General Provisions of the House). Most importantly, the House of Elders has a "special responsibility for passing laws relating to religion, traditions (culture) and security" (“Constitution”, article 57: General Provisions of the House). In accordance with such responsibilities members of the House of Elders must fulfill the same conditions as those elected to the House of Representatives with two extra requirements: they must be over forty-five years of age and they must have good knowledge of the religion (Islam) or be "well versed in the traditions" ("Constitution", article 59.1-2). The House of Elders has an innovative role which is the power of passing "legislation relating to religion, traditions (culture) and security" (“Constitution”, article 61.1).

Throughout the "Constitution" there is a strong connection between the traditional communities, Islam, and the desire to comply with contemporary and somehow universal parameters of law using methods of traditional dialogue and consultation. Thus, another duty of the House of Elders is to assist the government in matters relating to religion, security, defense, traditions (culture), economy and society in consultation with the traditional heads of communities ("Constitution", article 61.4). The House of Elders serves as an auditing body for the government in which a President and a Vice-President are elected, both of them having to be Muslims and who "must behave in accordance with the Islamic religion" ("Constitution", article 82.2). Once again, conditions of age prevail and candidates for President and Vice-President "must not be aged less than 40 years" ("Constitution”, article 82.3). A further condition for candidates to be President or Vice-President not mentioned for candidates to any of the Houses is that the candidate's spouse must also be Muslim ("Constitution", article 82.7).

Among the judicial organs assigned to the state for its running the "Constitution" makes provisions for the Ulema Council, an independent body that formulate formal declarations in the event of religious disagreements and "any matters in which there is a conflict as to whether they are contrary to the Sharia, or appear to the Council as being contrary to the Sharia" ("Constitution”, article 115.1. a-b). The Ulema Council has also a duty to conduct research from a religious perspective in order to advance religious knowledge particularly that related to translations of Sharia law works, those used in the courts and in the educational syllabus ("Constitution", article 115.2). The Ulema Council is made of eleven members, none of them less than forty years of age and 
known for their “piety (allegiance to Allah) and good manners” (“Constitution”, article 117.3). Within the legal and moral attributes of those elected to the Ulema Council the "Constitution" mentions that "a member shall observe neutrality in political matters and in religious views” (“Constitution”, article 117.6).

\section{The Problem of Constitutional Generations}

The Constitution of Somaliland provided a carta magna for the development of the Somaliland state and further revisions and critiques were aimed at enhancing the possibility of self-ordering and self-regulation. The threat to such exemplar path of state formation and state building after conflict came from the fear of an ever-presence of increasingly more powerful Islamic fundamentalists who would prefer to break with Western education and global constitutionalism. Among those, the Islamist movement Al-Shabab present in rural areas of Somalia continued being a point of attraction to unemployed youth and to those who found difficult to stop bearing arms in order to have influence within an independent Somaliland. Within these societal moments of conflict Islam as the common religion of all in Somaliland has acted as a unifying socio-religious and constitutional force. Such force has given legitimacy to political leaders who are exercising their political office vis-à-vis a state where all citizens are Muslims. This social formula of religious significance has worked for the most part throughout the contemporary Muslim world, the Horn of Africa and within countries of the Arab League. However, Islam as a unifying force has failed to unify Somalia and Djibouti, both countries with a majority Muslim population. In the case of Somaliland religion has become the solution rather than the problem.

Elsewhere, I have revisited the sociology of Karl Mannheim in order to reopen critical discussions on what Mannheim called "the problem of generations" within the creation, passing and understanding of knowledge within society (Mannheim, 1952) ${ }^{10}$. Mannheim pointed out the inadequacy of understanding generations only in a biological sense. While people follow a "biological rhythm in human existence”, they are also socially located, and that location gives them a tendency towards particular modes of behaviour, feelings, and thought. "Generational location” depends on a rhythm in human existence, according to Mannheim, and therefore relates to individuals and their particular year of birth and process of ageing. It is in that sense that individuals are socially located and assume some common location in the historical dimension of the social process (Aguilar, 1993: 4243).

The challenges of different generations in Somaliland in relation to the "Constitution" was to understand these generational tensions by which younger generations tend to challenge the customs and ethos of an older generation. Thus, instead of receiving a given knowledge they reinvent modes of knowledge that affect social practices creating a social tension that affects sociability and unity. This process of reinvention is more pronounced within periods of war, social violence and instability. The "Constitution" has mediated these tensions by integrating a full adherence to Islam and Sharia while allowing universal conceptions of human rights and the rights of women to be legal tenants within the "Constitution", thus mediating the possible tensions between generations based on religion, gender or class.

Anthony Lang, working within the possibilities and impossibilities of a global constitutionalism, has in the case of Egypt, asked the following: "Should a constitution be an ideal document guaranteeing international human rights or a compromise document that reflects the interests and powers of different actors in a societal context?”. In the case of Egypt Lang has argued that “its new constitution should be seen as a compromise between conflicting political interests that has created institutions within which claims for rights and responsibilities are still to be negotiated” (Lang, 2013: 345). Lang's argument opens an avenue to a diversity of diverse types of constitutionalism rather than the given product of a negotiated constitution that in the case of Somalia, for example, has created a rejection to a US imposed constitution.

The Constitution of Somaliland provides a social and political framework in which a bounded entity, a self-proclaimed state, has managed to provide the political and legal structures of a common identity within a clear unity in ethnicity and an ongoing positive and constructive tension between Islamic law and European law that has created not an ideal document but a document that allows actors within the political process to assess the structures of government, the stability of the country and the development of political, legal and financial institutions. If the trimmings of such constitution provide order and leadership it is because it allows for public accountability rather than patronage and clan alliances. Those traditional alliances can take place within rules of

\footnotetext{
${ }^{10}$ I applied the "problem of generations" in a socio-religious analysis of the conversion of the Waso Boorana of Kenya to Islam in the 1930s through a process which I termed “somalization” (Aguilar, 1998).
} 
accountability that extend to all citizens rather than to majority clans only.

The "problem of constitutional generations", a term I have coined, extends Mannheim's understanding of generations ("the problem of generations"). The "problem of constitutional generations" is a problem of social memory and generational experience whereby different generations have a different ethos because of the experiences they have confronted within history, be it a personal or a national history. The old generation longs for a time when their experience and rules were able to secure them a central place in society while the young challenge those rules in order to construct a future in which their memories could be central and paradigmatic for the social order. The old controlled the wisdom of the system of clans based Somaliland society and therefore were respected because they were able to mediate water and land disputes between the majority clans which in turn protected the minority clans. This traditional constitutional script was based on honour and clanship cooperation values that were maintained within the colonial period. However, with independence clans that were used to different territories competed for government roles in a traditional manner without paying attention to the possible structural and economic development of Somalia and Somaliland. The problem of constitutional generations, a problem on the making is to accommodate the different generations under a common umbrella in which challenges to others can be carried out within the open legality of the Houses of Parliament, avoiding the possibility of a no-go situation in which arms and violence, clan predominance and a lack of peace return. Within these ongoing possibilities of social and political violence there is no doubt that Islam as a unifying principle within Somaliland remains the solution to any strong generational and constitutional crisis that could arise.

\section{Conclusion}

Alicia Bannon has rightly argued that "there is a surprising lack of scholarly analysis of why particular constitution-writing processes succeed or fail” (Bannon, 2007: 1827-1828). This paper has aimed at filling that gap allowing for a scholarly, very general, analysis on the Constitution of Somaliland. This particular constitutional process succeeded because time and urgency were given to issues of state-building and peace-keeping from within. There was the will by the people of Somaliland to use traditional institutions of mediation and dialogue in order not to return to violence and suffering keeping in mind the violence still existent in neighbouring Somalia. The Somaliland Constitution has shown that religion could be the solution to violence and that constitutions can be expressions of dialogue and tension within communities that can express their aspirations with an absence of extreme violence. The problem of constitutional generations which I have posed in this paper is the ongoing problem of how to mediate the tensions between generations involved without returning to violence, generations that cannot be understood as biological entities to be measured but as social groups with an ethos and a social behaviour. Within such generational tensions interpretations regarding the formation, proclamation and implementation of a constitutional text can vary and must recognize that constitutional texts are and can only be compromises between conflicting political interests, or in the case of Somaliland between conflicting clan interests. Because the constitutional solution in Somaliland was based on Islam on the one hand and on traditional institutions on the other, two further papers will follow addressing religion (Islam) and traditional institutions (House of Elders) within Somaliland constitutionalism.

\section{References}

Abbink, J. (2009). The Total Somali Clan Genealogy (2nd ed.). ASC Working Papers 84, Leiden: African Studies Center.

Aguilar, M. I. (1993). Current Religious Practices and Generational Patterns among the Waso Boorana of Garba Tulla, Kenya. Ph.D. Thesis, London: School of Oriental and African Studies, University of London.

Aguilar, M. I. (1998). Being Oromo in Kenya. Trenton, NJ and Asmara: Africa World Press.

Aguilar, M. I. (2015). Muslim-State Relations in Kenya. In Mason, R. (Ed.). Muslim Minorities and the Modern State. New York: Palgrave.

Ahmed, A. J. (Ed.) (1995). The Invention of Somalia. Lawrenceville, NJ: The Red Sea Press.

Bannon, A. L. (2007). Designing a Constitution-Drafting Process: Lessons from Kenya. Yale Law Journal, 116, $1824-1872$. http://dx.doi.org/10.2307/20455777

Bradbury, M. (2008). Becoming Somaliland. London: Progressio. In Association with Oxford: James Currey, Bloomington and Indianapolis: Indiana University Press, Johannesburg: Jacana Media, Kampala: Fountain Publishers, and Nairobi: E.A.E.P. 
Cassanelli, L. V. (2006). Tradition to Text: Writing Local Somali History in the Travel Narratives of Charles Guillain (1846-48). Journal of African Cultural Studies, 18, 55-71. http://dx.doi.org/10.1080/13696850600750319

Cassanelli, L. V. (2010). Speculations on the Historical Origins of the “Total Somali Genealogy”. In M. V. Hoehne, \& V. Luling (Eds.), Peace and Milk, Drought and War: Somali Culture, Society and Politics-Essays in Honour of I.M. Lewis (pp. 53-66). London: Hurst \& Company.

Dastuurka Jamhuuriyadda Somaliland (2000). Translated into English by Ibrahim Hashi Jama as The Constitution of the Republic of Somaliland.

http://www.somalilandlaw.com/Somaliland Constitution/body somaliland constitution.htm

Helander, B. (1999). Somalia. In D. Westerlund, \& I. Svanberg (Eds.), Islam outside the Arab World (pp. 39-55). London: Palgrave Macmillan.

Hersi, A. A. (1977). The Arab Factor in Somali History. Unpublished Ph.D. Thesis, Los Angeles: University of California at Los Angeles.

Lang, A. F. (2013). From Revolutions to Constitutions: The Case of Egypt. International Affairs, 89, 345-363. http://dx.doi.org/10.1111/1468-2346.12021

Lewis, I. M. (1955). Peoples of the Horn of Africa: Somali, Afar and Saho, Ethnographic Survey of Africa, North Eastern Africa, Part I. London: International Institute.

Lewis, I. M. (1957). The Somali Lineage System and the Total Genealogy: A General Introduction to Basic Principles of Somali Political Institutions. Hargeisa: Somaliland Government.

Lewis, I. M. (1982). A Pastoral Democracy: A Study of Pastoralism and Politics among the Northern Somali of the Horn of Africa. New York: Africana Publishing Company for the International African Institute.

Lewis, I. M. (1994a). Peoples of the Horn of Africa: Somali, Afar and Saho. New Edition with Supplementary Appendixes, London: Haan.

Lewis, I. M. (1994b). Blood and Bone: The Call of Kinship in Somali Society. Lawrenceville, NJ: The Red Sea Press.

Lewis, I. M. (1994c). From Nomadism to Cultivation: The Expansion of Political Solidarity in Southern Somalia. In I. M. Lewis (Ed.), Blood and Bone: The Call of Kinship in Somali Society (pp. 133-148). Lawrenceville, NJ: The Red Sea Press.

Lewis, I. M. (1994d). The Rise of the Somali National Movement: A Case Study in Clan Politics. In I. M. Lewis (Ed.), Blood and Bone: The Call of Kinship in Somali Society (pp. 177-219). Lawrenceville, NJ: The Red Sea Press.

Lewis, I. M. (2001). Saints in North East African Islam. In B. S. Amoretti (Ed.), Islam in East Africa: New Sources (pp. 227-240). Rome: Herder.

Mannheim, K. (1952). The Problem of Generations. In P. Kecskemeti (Ed.), Essays on the Sociology of Knowledge (pp. 276-320). London: Routledge and Kegan Paul.

Mansur, A. O. (1995) The Nature of the Somali Clan System. In Ahmed, A. J., (Ed.), The Invention of Somalia (pp. 117-134). Lawrenceville, NJ: The Red Sea Press.

Mohamed Haji Mukhtar (1995). Islam in Somali History: Fact and Fiction. In Ahmed, A. J. (Ed.), The Invention of Somalia (pp. 1-27). Lawrenceville, NJ: The Red Sea Press.

Reese, S. (2008). Renewers of the Age: Holy Men and Social Discourse in Colonial Benadir. Leiden: Brill. http://dx.doi.org/10.1163/ej.9789004167292.i-247

Renders, M. (2007). Appropriate “Governance-Technology”?_-Somali Clan Elders and Institutions in the Making of the "Republic of Somaliland”. Africa Spectrum, 42, 439-459.

Somaliland Ministry of Foreign Affairs (2002). The Case for Somaliland's International Recognition as an Independent State. Briefing Paper, Hargeisa: Somaliland Government.

Walls, M. (2009). The Emergence of a Somali State: Building Peace from Civil War in Somaliland. African Affairs, 108, 371-389. http://dx.doi.org/10.1093/afraf/adp019

Walls, M. (2011). State Formation in Somaliland: Bringing Deliberation to Institutionalism. Unpublished Ph.D. Thesis, London: University College London, University of London. 